Article

\title{
Laser welding of panel joints of stainless steel heat exchangers
}

\author{
Aleksander Lisiecki ${ }^{1, *}$, Piotr Wójciga ${ }^{1}$, Agnieszka Kurc-Lisiecka ${ }^{2}$, Michał Barczyk ${ }^{3}$, Sonia Krawczyk ${ }^{3}$ \\ ${ }^{1}$ Silesian University of Technology, Poland \\ 2 WSB University in Chorzów, Poland \\ Agnieszka Kurc-Lisiecka Ph.D. Eng., a.kurc@wp.pl; \\ 3 P.U.T. FIRMUS, Olkusz, Poland \\ Michał Barczyk M.Sc. Eng., michal.barczyk@put-firmus.pl; \\ Sonia Krawczyk M.Sc. Eng., sonia.krawczyk@put-firmus.pl; \\ * Correspondence: Prof. Aleksander Lisiecki, aleksander.lisiecki@polsl.pl
}

Received: 30.04.2019; Accepted: 29.07.2019

\begin{abstract}
Results of study on the laser welding process of pillow plates heat exchangers are presented in the article. The influence of basic parameters of $\mathrm{CO}_{2}$ laser welding on the quality of overlap joints of AISI 304 stainless steel plates 2.0 and $4.0 \mathrm{~mm}$ thick was determined. The range of optimal parameters of welding, providing the highest quality and high mechanical performance of the test joints was determined. The technological conditions elaborated during the study were applied for manufacturing of the real pillow plates heat exchangers with dimensions of $1.5 \times 1.5 \mathrm{~m}$.
\end{abstract}

Keywords: laser welding; pillow plates; austenitic stainless steel

\section{Introduction}

Panel heat exchangers (cooling and heating jackets) are made of two sheets of the same or different

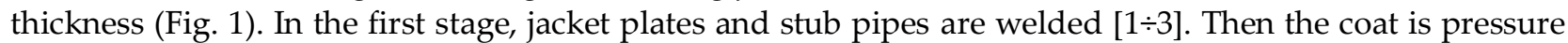
expanded. In the case of sheets of equal thickness, a symmetrical panel is obtained, while in the second case, thicker sheets are not deformed [1,4]. In the welding process, straight welds are made along the perimeter of the jacket (closing the plate) and circular welds in the central part, arranged according to various patterns. Pressure forming of the heat exchanger jacket occurs by expanding the space between the sheets in such a way that liquid (e.g. water) or compressed gas is introduced through the connector at the appropriate expansion pressure.

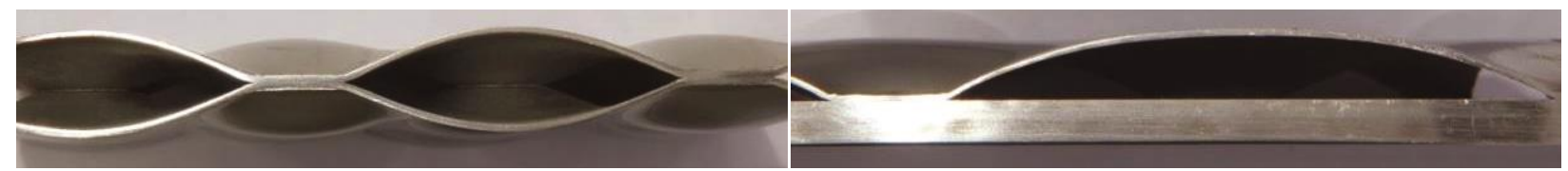

(a)

(b)

Fig. 1. Basic types of heat exchanger panels: a) symmetrical from sheets of equal thickness, b) asymmetrical from sheets of various thickness [1]

Therefore, the welds must have high strength and ensure tightness. At the same time, it is important that during welding there is no melting of the bottom sheet, or even its deformation, or overheating resulting in the appearance of heat tint, because the surface of the bottom sheet is the internal working surface of the exchanger $[1,5 \div 9]$. Coats for process tanks and heat exchangers are made of acid-resistant austenitic steel that meets the requirements of the food industry. This steel has good plastic properties required during pressure forming of panels and very good corrosion resistance $[1 \div 4]$.

\section{Stand and research materials}

Technological tests of laser welding were performed using the automatic station for welding and cutting 3D TruLaser Cell 7040 by TRUMPF in the company P.U.T. FIRMUS in Olkusz. The station is equipped with a CO2 laser generator TruFlow 4000 with a maximum power of $4.0 \mathrm{~kW}$ and a wavelength of $10.6 \mu \mathrm{m}$, and the chamber working space is $4000 \times 1500 \times 750 \mathrm{~mm}$ (Fig. 2). 


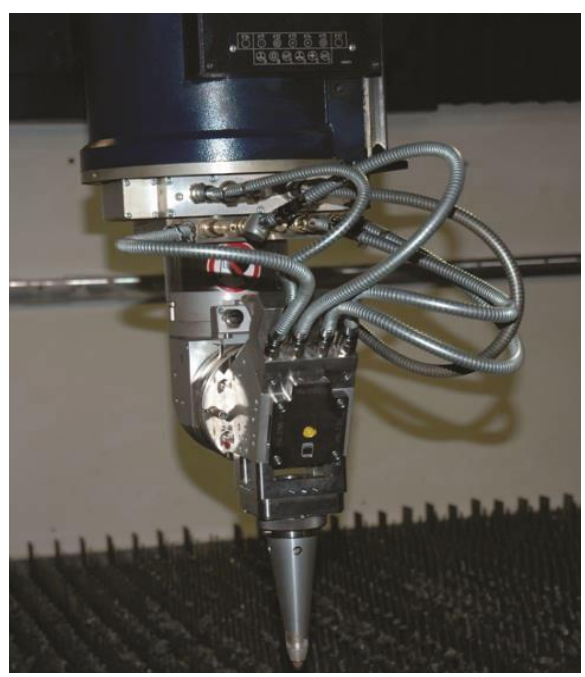

Fig. 2. View of the laser head for 3D laser welding at the Trulaser Cell 7040 station

The $50 \mathrm{~mm}$ wide test samples were cut from $2.0 \mathrm{~mm}$ and $4.0 \mathrm{~mm}$ AISI 304 steel sheets, which were selected by the customer for the production of cooling and heating heat exchangers (Fig. 3). AISI 304 steel is chromium-nickel steel ( $\mathrm{Cr}-\mathrm{Ni}$ ) with an austenitic structure and is characterized by very good corrosion and acid resistance, as well as the possibility of cold forming due to good plastic properties, it is also considered well weldable. The chemical composition and properties of AISI 304 steel are presented in tables I and II.
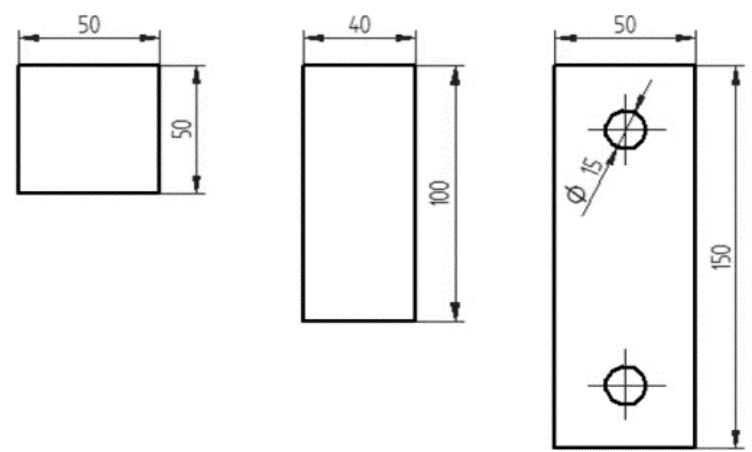

Fig. 3. The shape and dimensions of samples cut from austenitic steel sheets AISI 304 with a thickness of 2.0 and $4.0 \mathrm{~mm}$ for testing the process of welding with $\mathrm{CO}_{2}$ laser

In order to ensure high repeatability and accuracy of fastening, a special grip with elements for positioning the samples and preventing deformation during welding was designed and made. The method of fixing square-shaped samples intended for straight-line and circular welding tests is shown in figure 4 .
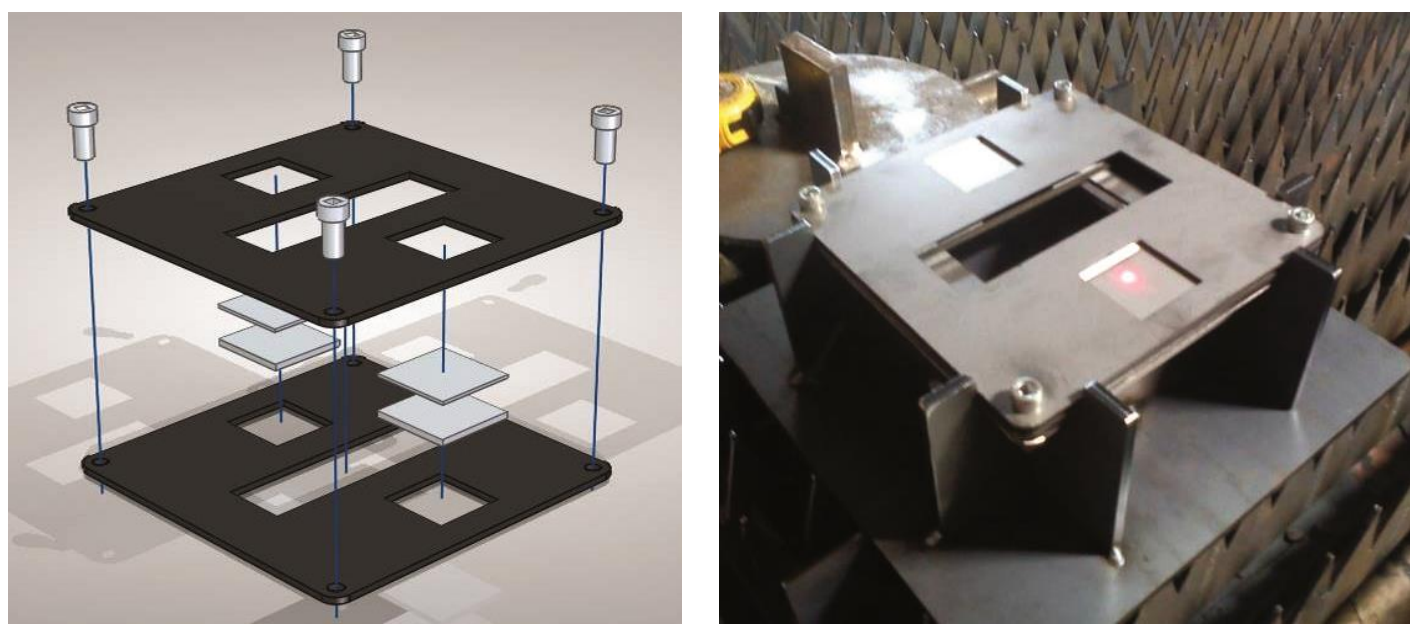

Fig. 4. The method of fixing samples with dimensions of $50 \times 50 \mathrm{~mm}$ made of austenitic steel with a thickness of $2.0 \mathrm{~mm}$ and $4.0 \mathrm{~mm}$ in a special holder prepared for testing of the laser welding process 
Table I. Chemical composition of the AISI 304 austenitic steel

\begin{tabular}{|c|c|c|c|c|c|c|c|}
\hline \multicolumn{8}{|c|}{ Chemical composition [\%] } \\
\hline $\mathrm{C}$ & Si & Mn & $\mathbf{P}$ & $\mathrm{S}$ & $\mathbf{N}$ & $\mathrm{Cr}$ & $\mathrm{Ni}$ \\
\hline $\max 0,07$ & $\max 1,0$ & $\max 2,0$ & $\max 0,045$ & $\max 0,015$ & $\max 0,11$ & $17,50 \div 19,50$ & $8,00 \div 10,50$ \\
\hline
\end{tabular}

Table II. Mechanical properties of the AISI 304 austenitic steel

\begin{tabular}{cccc}
\hline $\begin{array}{c}\text { The yield point } \\
\text { Re [MPa] }\end{array}$ & $\begin{array}{c}\text { Tensile strength } \\
\text { Rm [MPa] }\end{array}$ & $\begin{array}{c}\text { Elongation } \\
\text { A5 [\%] }\end{array}$ & $\begin{array}{c}\text { Hardness } \\
\text { [HB] }\end{array}$ \\
\hline $\min 230$ & $540 \div 750$ & $\min 45$ & $\max 215$ \\
\hline
\end{tabular}

\section{Course of the research}

The aim of the research was to analyze the impact of basic welding process parameters using the technique without additional material of lap joints of AISI 304 steel sheets with a thickness of 2.0 and $4.0 \mathrm{~mm}$ on the quality, structure and properties of test joints and determining the range of optimal welding parameters for panel heat exchangers.

Initial tests of laser welding without additional material were carried out using samples of dimensions $50 \times 50 \mathrm{~mm}$ in such a way that the sample with a smaller thickness of $2.0 \mathrm{~mm}$ was laid from above on a sample with a thickness of $4.0 \mathrm{~mm}$ (Fig. 4 and Fig. 5). Simulating the welding process of a laser heat exchanger jacket, $40 \mathrm{~mm}$ long straight and $15 \mathrm{~mm}$ circular welds were made with various welding process parameters. In the first stage of research, the effect of the laser beam focus relative to the upper surface of joined sheets on the shape and quality of straight joints was analyzed. Welding tests were carried out with the laser beam focusing on the upper surface of the sheet $2.0 \mathrm{~mm}$ thick (focus position $0 \mathrm{~mm}$ ), $2.0 \mathrm{~mm}$ above the upper surface of the sheet $(+2.0 \mathrm{~mm})$ and at the joint of joined sheets $(-2.0 \mathrm{~mm})($ Fig. 5 , and Fig. 6 , Table III). In the next stage, the influence of welding speed and laser beam power on the shape and quality of welds was examined (Fig. 6, Table III).

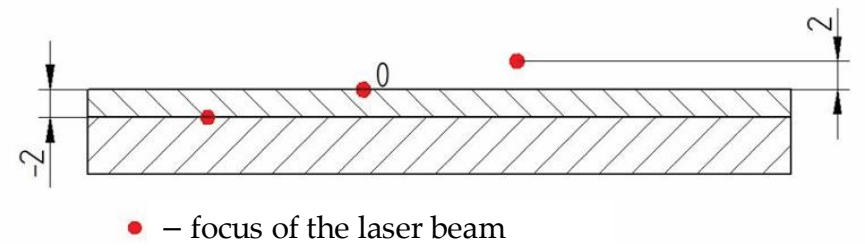

Fig. 5. Scheme of focusing the laser beam in relation to the upper surface of the joined sheets of AISI 304 austenitic steel with a thickness of $2.0 \mathrm{~mm}$ and $4.0 \mathrm{~mm}$ welded with a $\mathrm{CO}_{2}$ gas laser

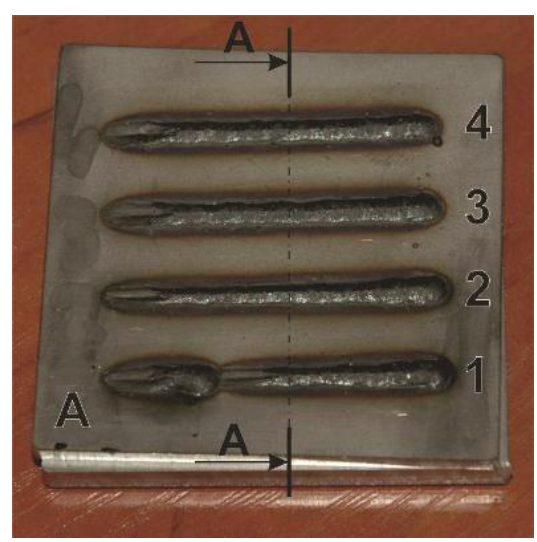

(a)

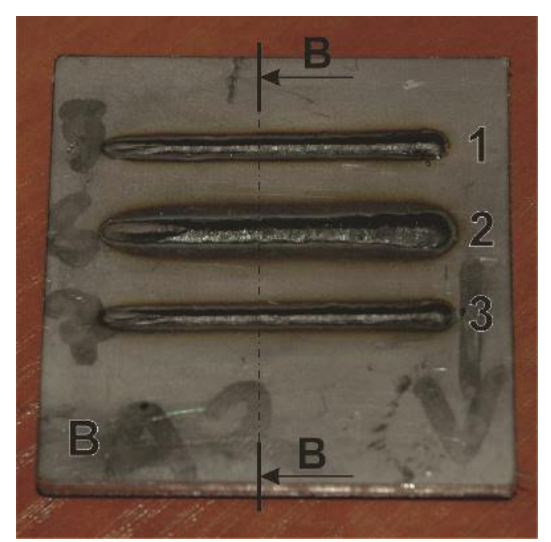

(b)

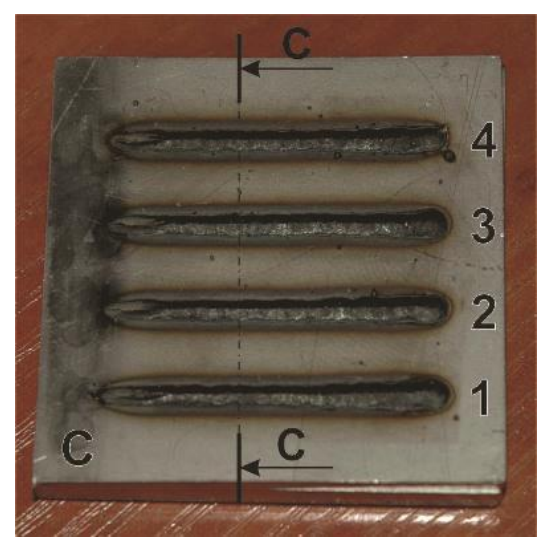

(c)

Fig. 6. View of test lap joints of AISI 304 sheets with a thickness of $2.0 \mathrm{~mm}$ and $4.0 \mathrm{~mm}$ welded with a $\mathrm{CO}_{2}$ gas laser with straight welds (Table III): a) joint A, b) joint B, c) joint C

Figure 6 shows the intersection of samples for further metallographic testing. Microscopic observations were carried out using an OLYMPUS GX71 metallographic microscope with a magnification in the range of 50 to 1000x. On metallographic specimen surfaces, hardness measurements were made using a Wilson Wolpert Micro-Vickers 401 MVD hardness tester in accordance with PN-EN 6507-1. The microhardness was tested at $0.2 \mathrm{~kg}$ load for 5 seconds. 
Table III. Parameters of $\mathrm{CO}_{2}$ gas laser welding of test lap joints made of AISI 304 austenitic steel sheets with a thickness of $2.0 \mathrm{~mm}$ and $4.0 \mathrm{~mm}$ with straight welds (Fig. 6)

\begin{tabular}{|c|c|c|c|c|c|}
\hline $\begin{array}{c}\text { Joint's } \\
\text { designation }\end{array}$ & $\begin{array}{c}\text { Weld's } \\
\text { designation }\end{array}$ & $\begin{array}{c}\text { Laser beam } \\
\text { power } \\
{[W]}\end{array}$ & $\begin{array}{l}\text { Welding speed } \\
{[\mathrm{m} / \mathrm{min}]}\end{array}$ & $\begin{array}{c}\text { Focus position of } \\
\text { the laser beam } \\
{[\mathrm{mm}]}\end{array}$ & Comments \\
\hline \multirow{4}{*}{ A } & 1 & 4000 & 1,5 & -2 & $\mathrm{BP}, \mathrm{SL}$ \\
\hline & 2 & 4000 & 1,5 & -2 & $\mathrm{BP}, \mathrm{SL}$ \\
\hline & 3 & 4000 & 1,5 & 0 & $\mathrm{BP}, \mathrm{SL}$ \\
\hline & 4 & 4000 & 1,5 & 2 & $\mathrm{BP}, \mathrm{SL}$ \\
\hline \multirow{3}{*}{ B } & 1 & 4000 & 2,5 & -2 & $\mathrm{BP}, \mathrm{WL}$ \\
\hline & 2 & 4000 & 1,0 & -2 & $\mathrm{BP}, \mathrm{SL}, \mathrm{PP}$ \\
\hline & 3 & 4000 & 3,0 & -2 & $\mathrm{BP}, \mathrm{WL}$ \\
\hline \multirow{4}{*}{$\mathrm{C}$} & 1 & 3750 & 1,5 & -2 & $\mathrm{BP}$ \\
\hline & 2 & 3500 & 1,5 & -2 & $\mathrm{BP}$ \\
\hline & 3 & 3250 & 1,5 & -2 & $\mathrm{BP}$ \\
\hline & 4 & 3000 & 1,5 & -2 & $\mathrm{BP}$ \\
\hline
\end{tabular}

Notes: shielding gas flow rate (Ar) 5 l/min, BP - no cracks, SL - wide weld face, PP - full penetration, WL - narrow weld face

Then, test joints were made with circular welds with a diameter of $15 \mathrm{~mm}$ at different laser beam power. Due to the different thermal conditions of welding the lap joints with small diameter circular welds and the temperature increase at the welding site, it was necessary to reduce the welding energy compared to straight weld joints (Table IV, Fig. 7). In the case of circular welds, microscopic observations were carried out in two opposite planes of the weld, and the place of intersection of the samples and the plane of microscopic observations is shown in figure 7.

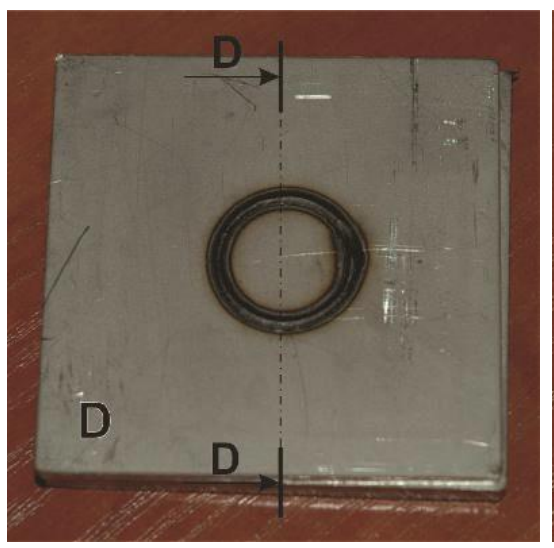

(a)

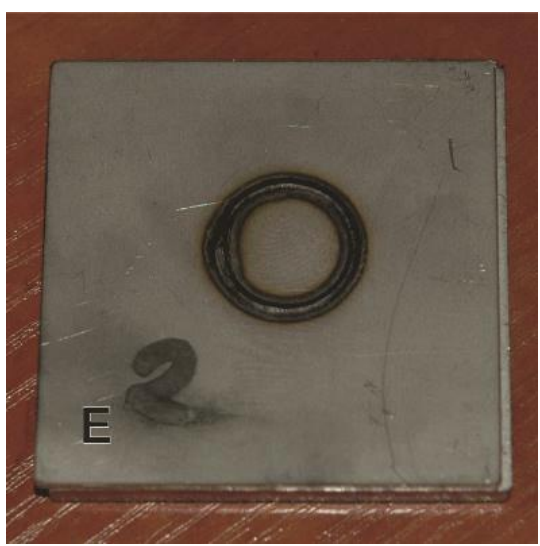

(b)

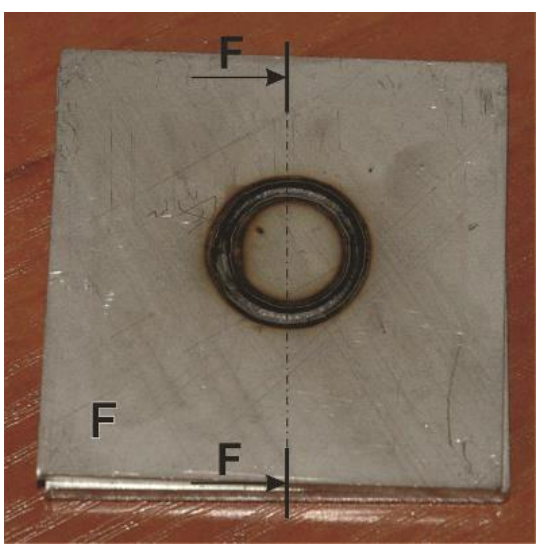

(c)

Fig. 7. View of test lap joints of AISI 304 sheets with a thickness of $2.0 \mathrm{~mm}$ and $4.0 \mathrm{~mm}$ welded with a $\mathrm{CO}_{2}$ gas laser with circular welds (Table IV): a) joint D, b) joint E, c) joint F

Metallographic observations were carried out on transverse grinded and mechanically polished specimens. In order to reveal the structure, the metallographic specimens were digested in the Adler reagent with the chemical composition: $35 \%$ hydrochloric acid, iron chloride $\left(\mathrm{FeCl}_{3} \times 6 \mathrm{H}_{2} \mathrm{O}\right)$, ammonium chloride $\left(\mathrm{NH}_{4} \mathrm{Cl}\right)$ and copper chloride $\left(\mathrm{CuCl}_{2}\right)$. The macro- and microstructure observations of the test joints were carried out at 50x and 200x magnifications.

Table IV. Welding parameters of test lap joints with a circular weld of $15 \mathrm{~mm}$ diameter made of AISI 304 austenitic steel, thickness: $2.0 \mathrm{~mm}$ and $4.0 \mathrm{~mm}$, welded with a $\mathrm{CO}_{2}$ gas laser (Fig. 7)

\begin{tabular}{ccccc}
\hline $\begin{array}{c}\text { Joint's } \\
\text { designation }\end{array}$ & $\begin{array}{c}\text { Laser beam power } \\
{[\mathrm{W}]}\end{array}$ & $\begin{array}{c}\text { Welding speed } \\
{[\mathrm{m} / \mathrm{min}]}\end{array}$ & $\begin{array}{c}\text { Focus position of the la- } \\
\text { ser beam [mm] }\end{array}$ & Comments \\
\hline $\mathrm{D}$ & 2500 & 2,5 & -2 & $\mathrm{BP}, \mathrm{WL}$ \\
$\mathrm{E}$ & 3000 & 2,5 & -2 & $\mathrm{BP}, \mathrm{WL}$ \\
$\mathrm{F}$ & 3500 & 2,5 & -2 & $\mathrm{BP}, \mathrm{WL}$ \\
\hline
\end{tabular}

Notes: shielding gas flow rate (Ar) 5 l/min, BP - no cracks, WL - narrow weld face 
Based on visual, macro- and microscopic metallographic tests and microhardness measurements, the impact of basic laser welding parameters on the penetration depth, shape and quality of the weld was determined. In order to assess the mechanical properties, mainly the tensile strength of the test joints, lap joints with straight joints and cross-joints with circular joints were designed for static tensile testing. Static tensile tests were performed using a Zwick Z/100 testing machine with a maximum tensile force of $100 \mathrm{kN}$ equipped with an extensometer (WN: 151855) for measuring elongation and a force measuring head ID: 0 WN: 151856 $100 \mathrm{kN}$.

Test joints for mechanical tests with straight welds were made with a maximum laser beam power of $4.0 \mathrm{~kW}$ focused at the contact of the sheets (focus position $-2.0 \mathrm{~mm}$ ) and at different welding speeds $1.5 \mathrm{~m} / \mathrm{min}$ and $2.5 \mathrm{~m} / \mathrm{min}$ (Fig. 8). Then, tensile samples were cut out from the test lap joints in accordance with PN-EN ISO 4136, and the dimensions of the samples and the method of implementation are shown in figures $9 \div 11$.

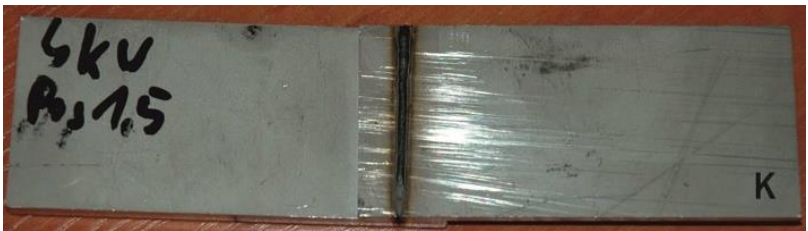

(a)

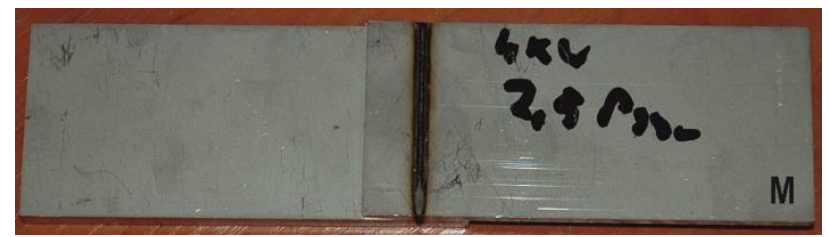

(b)

Fig. 8. View of test lap joints of AISI 304 sheets with a thickness of $2.0 \mathrm{~mm}$ and $4.0 \mathrm{~mm}$ welded with a $\mathrm{CO}_{2}$ gas laser with straight welds designed for a static tensile test: a) joint welded with a speed of $1.5 \mathrm{~m} / \mathrm{min}$ and $4.0 \mathrm{~kW}$ power, b) joint welded with a speed of $2.5 \mathrm{~m} / \mathrm{min}$ and power $4.0 \mathrm{~kW}$

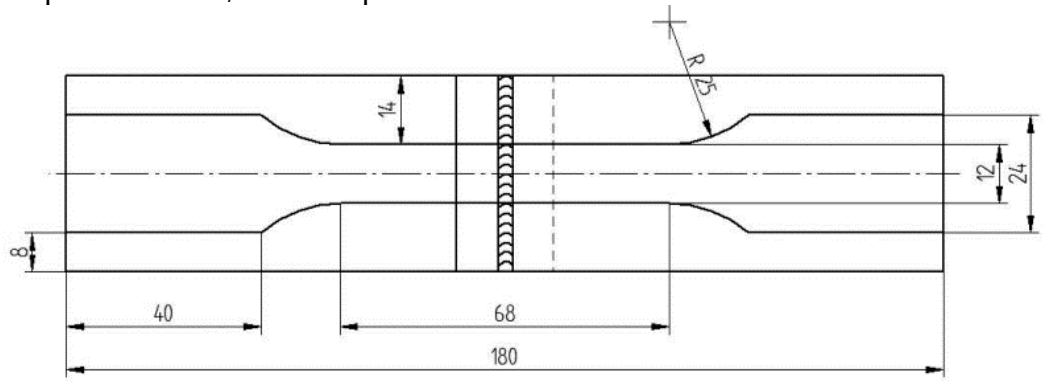

Fig. 9. Shape and dimensions as well as the method of making samples from the lap joints with a straight weld for a static tensile test

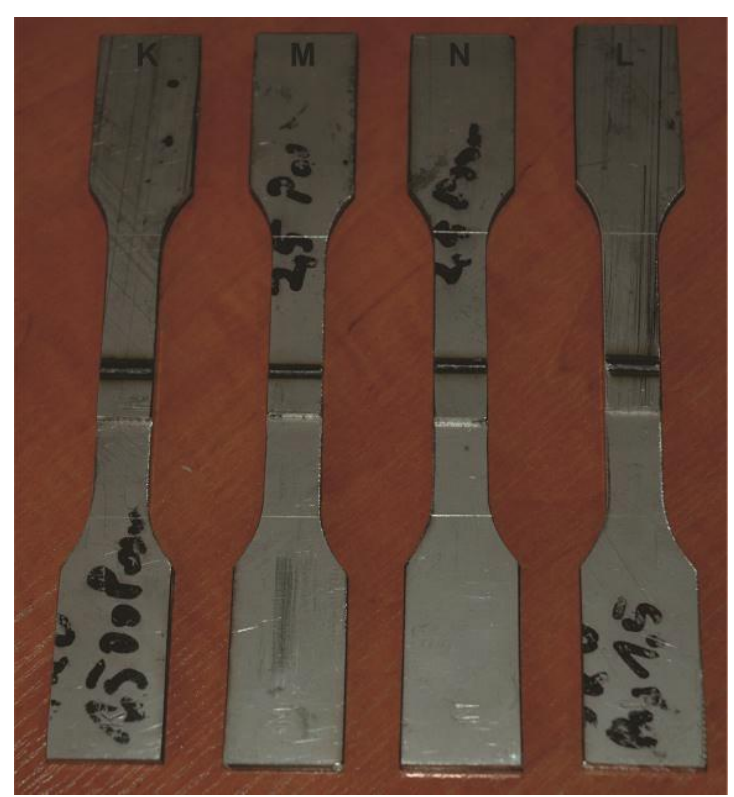

(a)

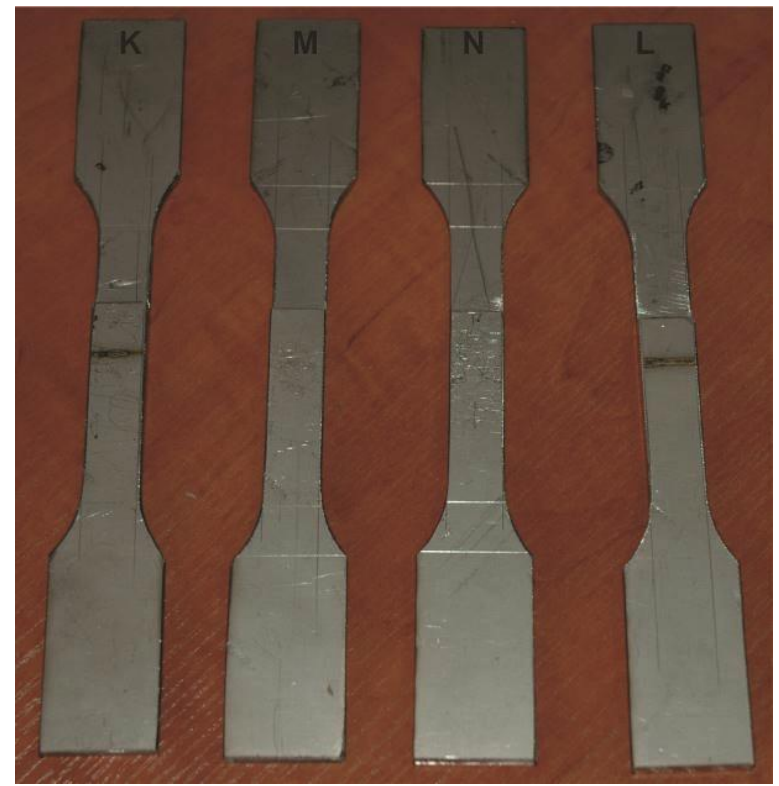

(b)

Fig. 10. View of the samples for static tensile test taken from lap joints of AISI 304 sheets with a thickness of $2.0 \mathrm{~mm}$ and $4.0 \mathrm{~mm}$ welded with a $\mathrm{CO}_{2}$ gas laser with straight welds (welding parameters: $\mathrm{K}, \mathrm{L}: 4.0 \mathrm{~kW}, 1.5 \mathrm{M} \mathrm{min}, \mathrm{M}, \mathrm{N}: 4.0 \mathrm{~kW}$, $2.5 \mathrm{M} / \mathrm{min}$ ): a) view of the upper surface of the joint and face of the weld, b) view of the bottom surface of the joint 


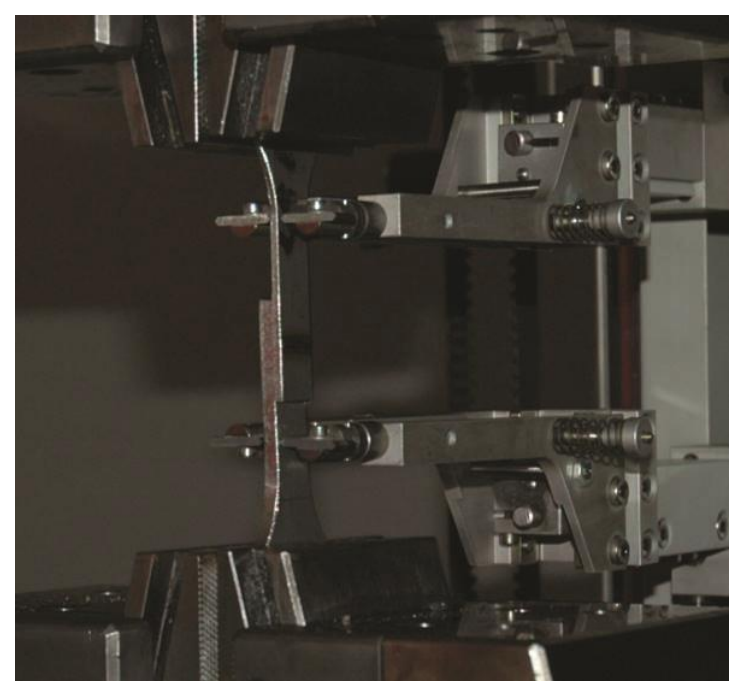

(a)

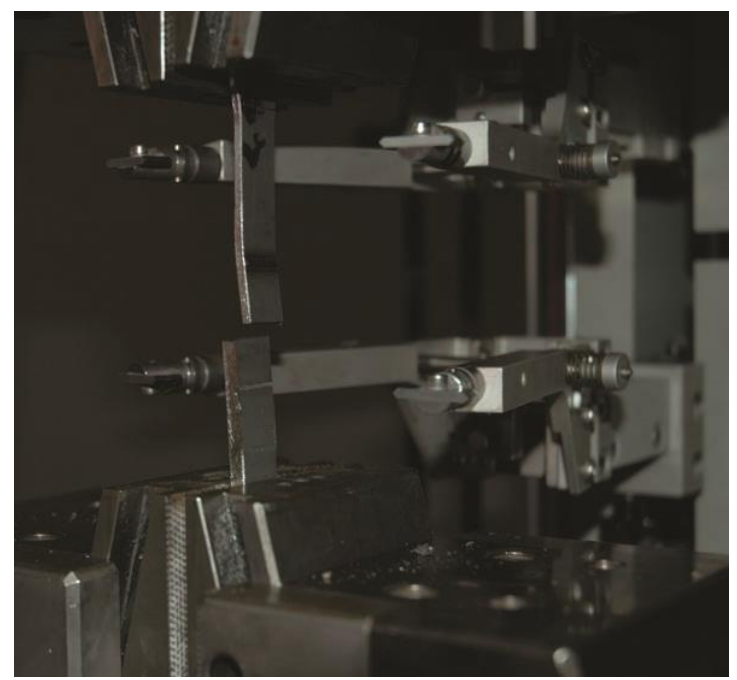

(b)

Fig. 11. View of: a) a lap joint sample with a straight weld fixed in the jaws of a testing machine during the tensile test and $b$ ) a ruptured sample at the weld location

In the case of joints with circular welds, special samples have been prepared with holes for mounting in the holder enabling even stretching of the samples (Fig. 12 $\div 15$ ). The shape and dimensions of cruciform samples with a circular stretching joint were adopted according to the guidelines of the Welding Institute No. W-2000/IS-ZR5, as for the assessment of suitability for spot and projection welding of sheets for an overlap. Samples for mechanical tests with circular welds were made at the same welding speed $2.5 \mathrm{~m} / \mathrm{min}$ and different power $2.5 \mathrm{~kW}$ and $3.0 \mathrm{~kW}$, with the laser beam focusing at the contact of the sheets (focus position $-2.0 \mathrm{~mm}$ ) (Fig. 13).

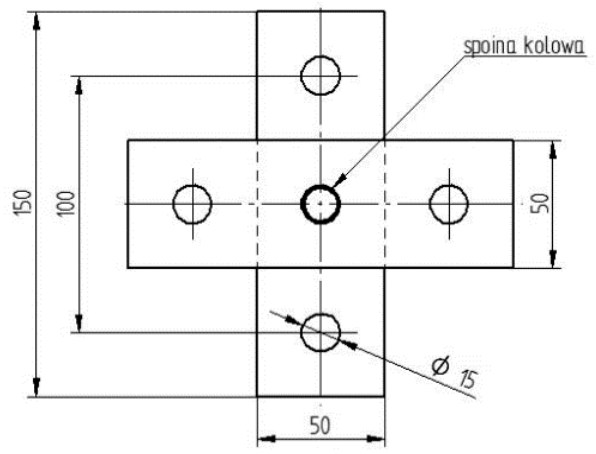

Fig. 12. The shape and dimensions of the cross samples for the tensile test

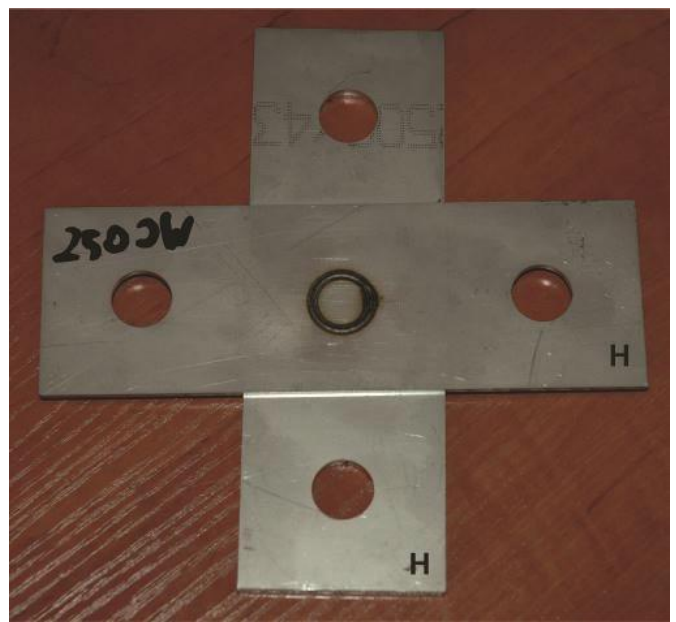

(a)

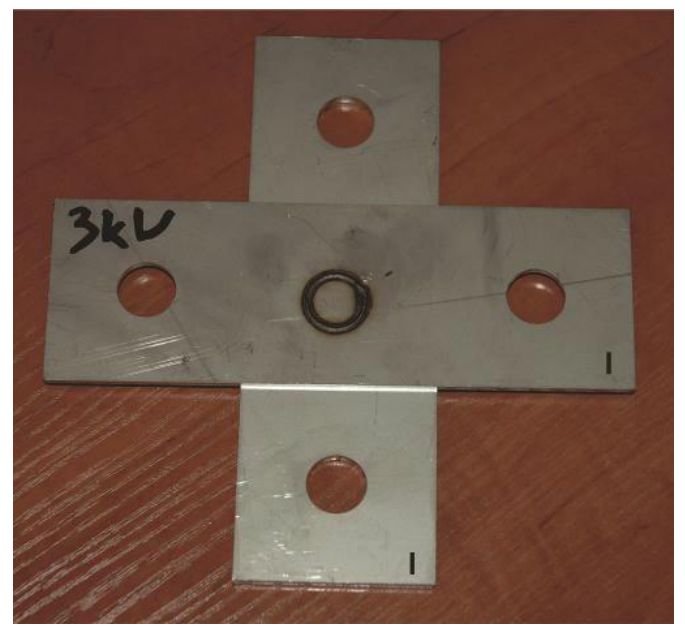

(b)

Fig. 13. View of test lap joints of AISI 304 sheets with a thickness of $2.0 \mathrm{~mm}$ and $4.0 \mathrm{~mm}$ welded with a $\mathrm{CO}_{2}$ gas laser with circular welds designed for static tensile test: a) joint welded with a speed of $2.5 \mathrm{~m} / \mathrm{min}$ and $2.5 \mathrm{~kW}$, b) joint welded with a speed of $2.5 \mathrm{~m} / \mathrm{min}$ and a power of $3.0 \mathrm{~kW}$ 


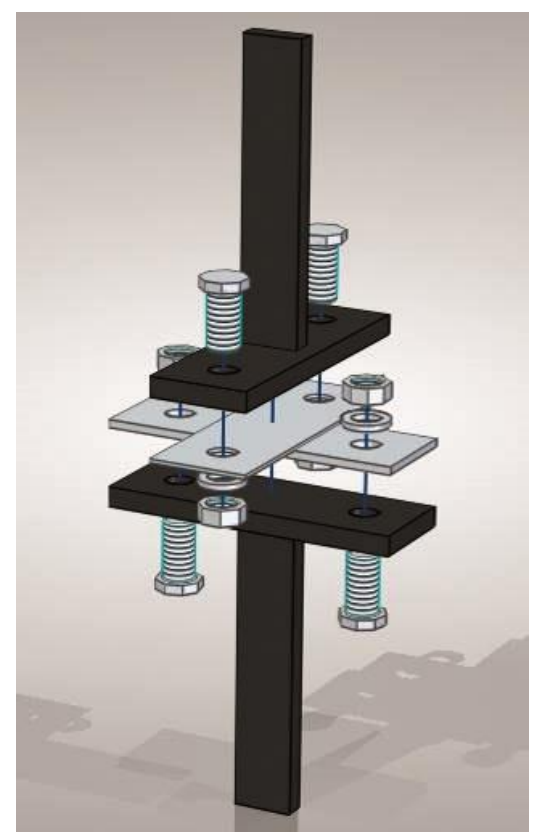

(a)

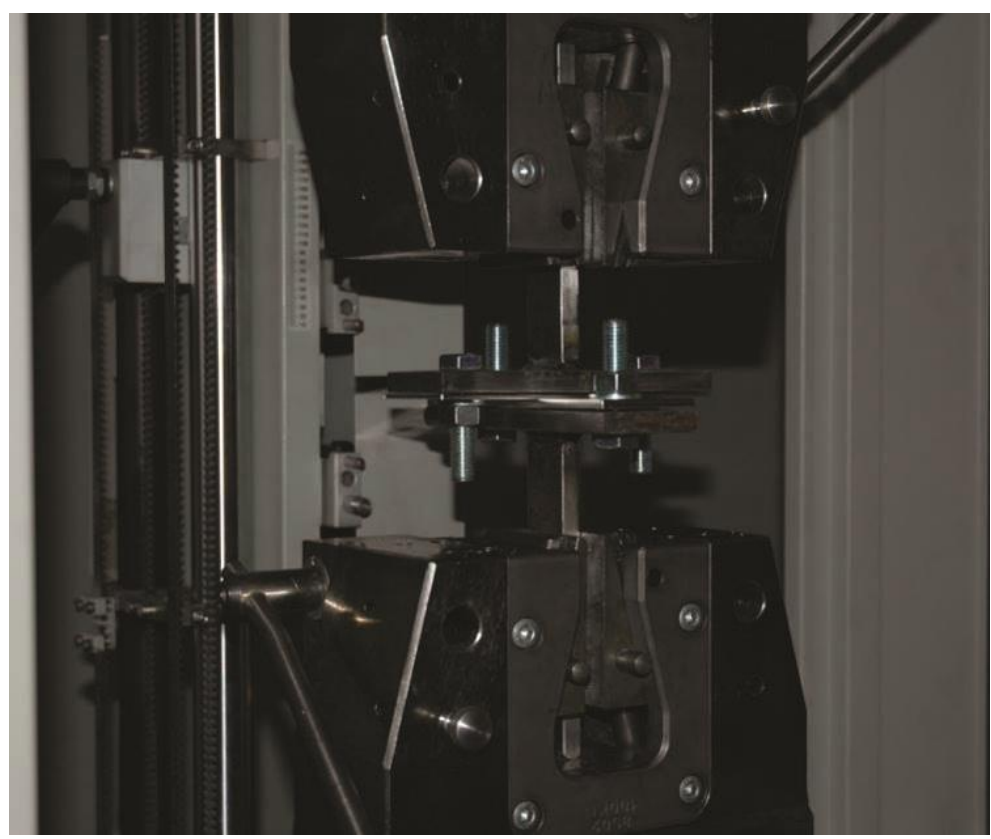

(b)

Fig. 14. a) The model of the holder for fixing the cross samples, b)the view of the holder mounted in the jaws of the testing machine before stretching the cross samples

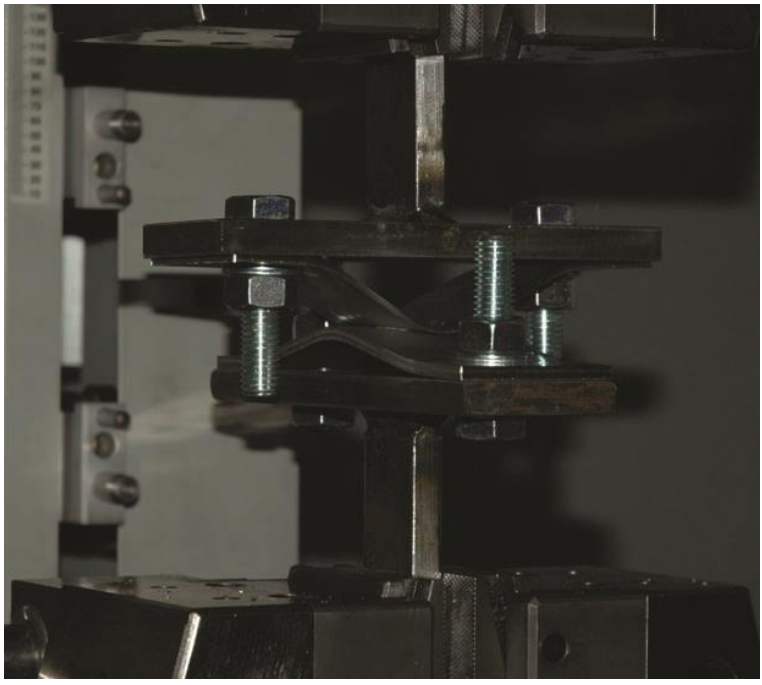

(a)

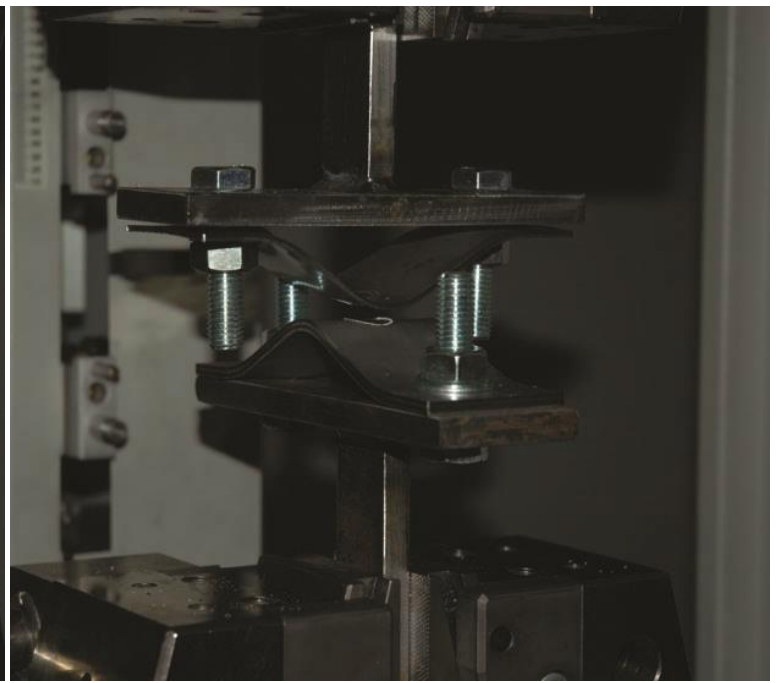

(b)

Fig. 15. View of: a) a cross sample with a circular weld during the static tensile test and b) a sample after a rupture in the weld

\section{Test results and their analysis}

AISI 304 austenitic steel used for the production of cooling and heating jackets for heat exchangers belongs to the group of well weldable steels. Research on the laser welding process of lap joints of AISI 304 austenitic steel sheets with a thickness of 2.0 and $4.0 \mathrm{~mm}$ using a $4000 \mathrm{~W} \mathrm{CO}_{2}$ gas laser has shown that it is possible to provide high quality joints with both straight and circular welds, but this requires proper selection of welding parameters. The main parameters determining the stability of the laser welding process and the quality of joints are the laser beam power, welding speed and the location of the laser beam focus relative to the upper surface of the connector.

The position of the laser beam focus relative to the upper surface of the joined sheets does not affect the welding linear energy, but causes a significant change in the laser beam power density on the upper surface of the joint (upper sheet), the mechanism of heating and remelting the sheets, and thus significantly affects the shape and depth of fusion (Fig. 16). It was found that the greatest penetration depth is ensured by focusing the laser beam not on the upper surface of the thinner sheet, but in the contact plane of the sheet $(2.0 \mathrm{~mm}$ below the upper sheet surface). At the same time, as the distance between the laser beam focus and the metal 
contact plane increases, the width of the weld face increases and the penetration depth decreases. However, due to the socket shape of the weld, the penetration width at the joint of joined sheets is constant, regardless of how the laser beam focuses in the tested range. Therefore, it was decided that further welding tests would be carried out while focusing the laser beam in the contact plane of the lap joint sheets.

The linear energy range of laser welding during the performance of test lap joints, straight welds, AISI 304 steel sheets with a thickness of 2.0 and $4.0 \mathrm{~mm}$ ranged from $80 \mathrm{~J} / \mathrm{mm}(4.0 \mathrm{~kW}, 3.0 \mathrm{~m} / \mathrm{min})$ to $240 \mathrm{~J} / \mathrm{mm}(4.0$ $\mathrm{kW}, 1.0 \mathrm{~m} / \mathrm{min}$ ) (Fig. 17). At the lowest welding energy of $80 \mathrm{~J} / \mathrm{mm}$, the depth of fusion in the lower straight weld plate is small and does not exceed $1.5 \mathrm{~mm}$, and the width of the weld joint at the sheet metal is less than $1.0 \mathrm{~mm}$ (Fig. 17c).

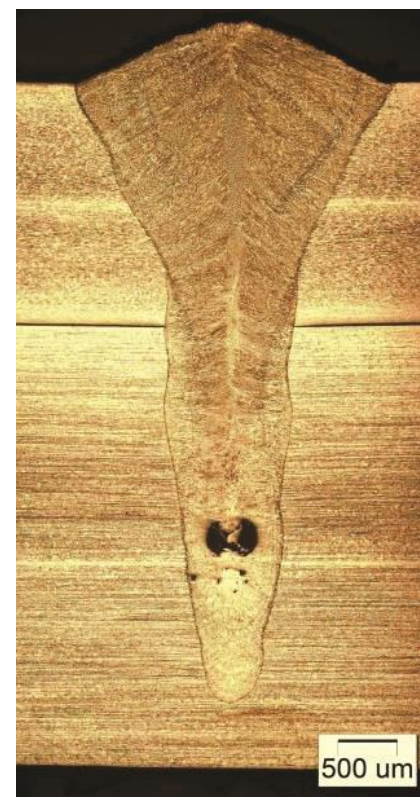

(a)

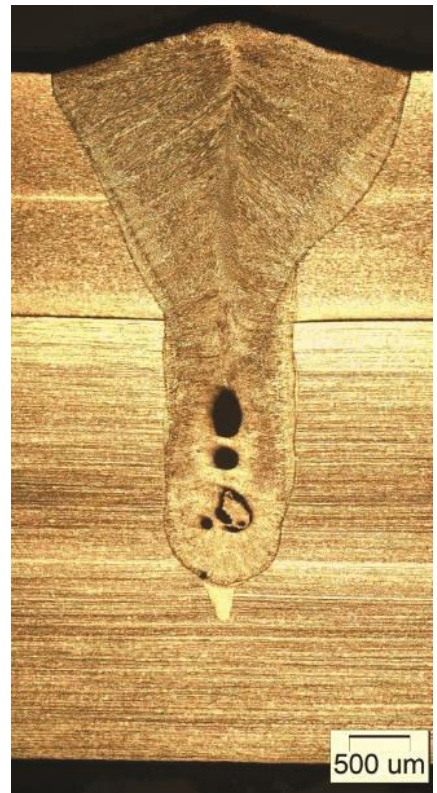

(b)

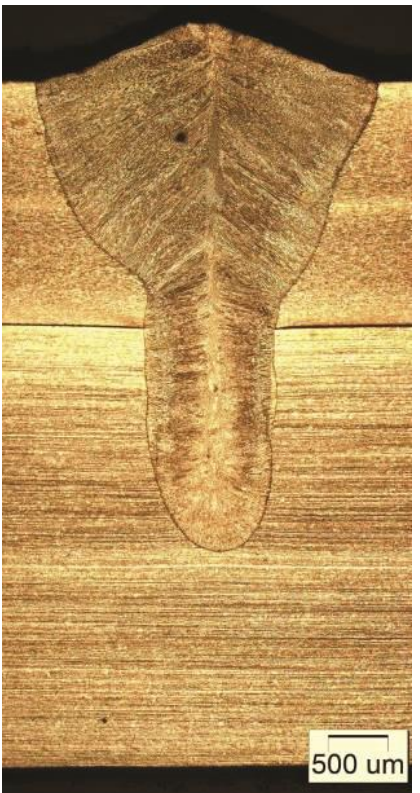

(c)

Fig. 16. Effect of the focusing method (location of the laser beam focus plane with respect to the upper joint surface) of the laser beam to the depth of penetration and the shape of a straight weld of the lap joints of AISI 304 sheets with a thickness of $2.0 \mathrm{~mm}$ and $4.0 \mathrm{~mm}$ welded with a $\mathrm{CO}_{2}$ gas laser with a power of 4,0 kW, speed $1.5 \mathrm{~m} / \mathrm{min}$ : a) focussing the laser beam in the plane of contact of the sheets $(-2.0 \mathrm{~mm})$; b) focusing the laser beam on the upper surface of the sheet $(0.0 \mathrm{~mm})$; c) focusing the laser beam $2.0 \mathrm{~mm}$ over the upper surface of the sheet $(+2,0 \mathrm{~mm})$

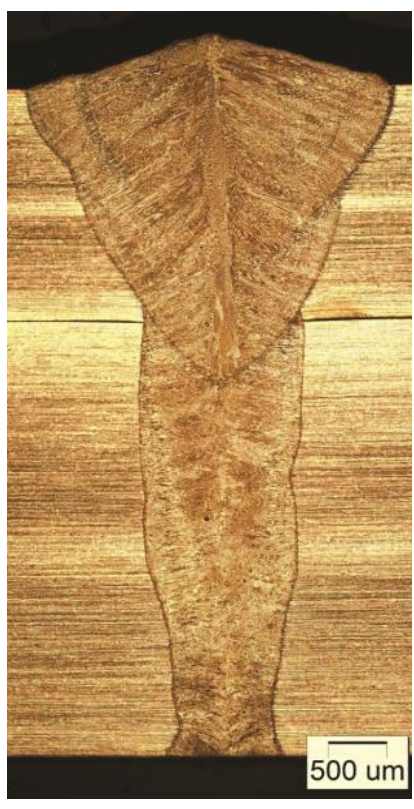

(a)

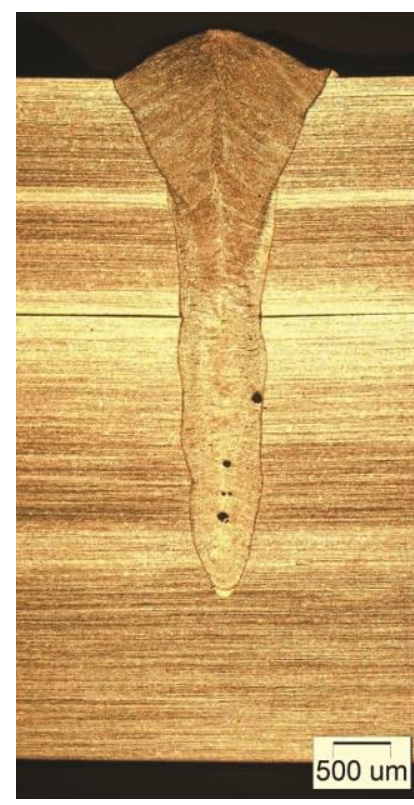

(b)

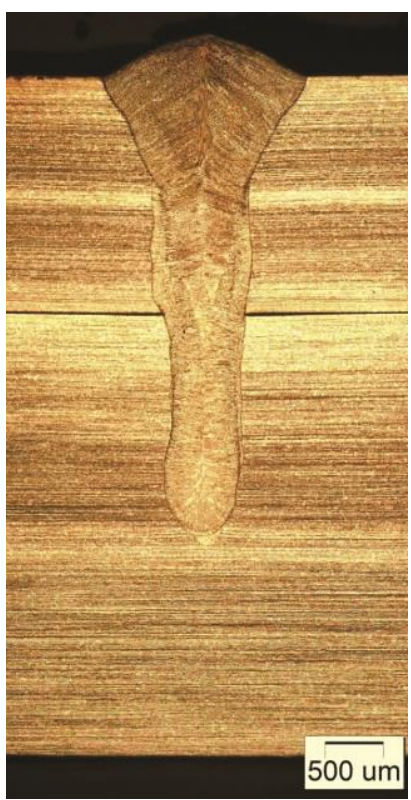

(c)

Fig. 17. Influence of the welding speed on the penetration depth and the shape of a straight weld of the lap joints of AISI 304 sheets with a thickness of $2.0 \mathrm{~mm}$ and $4.0 \mathrm{~mm}$ welded with a $\mathrm{CO}_{2}$ gas laser with a power of $4.0 \mathrm{~kW}$, with focusing of the laser beam in the plane of contact of the sheets; a) $1.0 \mathrm{~m} / \mathrm{min}, \mathrm{b}) 2.5 \mathrm{~m} / \mathrm{min}, \mathrm{c}) 3.0 \mathrm{~m} / \mathrm{min}$ 
Too low penetration depth of the weld into the lower plate is not beneficial, because it increases the risk of lack of penetration in the conditions of production welding of heat exchanger jacket. In turn, the width of the weld at the contact of the sheets determines the mechanical strength of the lap joint. With this joint configuration, it is beneficial to strive for a joint width equal to the thickness of the thinner sheet metal. Increasing the linear energy of laser welding to $160 \mathrm{~J} / \mathrm{mm}(4.0 \mathrm{~kW}, 1.5 \mathrm{~m} / \mathrm{min})$ ensures an increase in penetration depth of up to approx. $3.5 \mathrm{~mm}$ in the bottom sheet with a thickness of $4.0 \mathrm{~mm}$ (Fig. 16a). A further increase in the welding's linear energy up to $240 \mathrm{~J} / \mathrm{mm}(4.0 \mathrm{~kW}, 1.0 \mathrm{~m} / \mathrm{min})$ caused the sheet to be melted through (Fig. 17a). This case is unacceptable due to the requirements and quality criteria for the manufacture of panel heat exchangers, because the inner surface of the exchanger is a working surface and should be flat, even and without discoloration (tarnish). Therefore, a welding speed of $1.5 \mathrm{~m} / \mathrm{min}$ was considered optimal with a maximum laser beam power of $4.0 \mathrm{~kW}$ of the $\mathrm{CO}_{2}$ gas laser used. Analysis of the impact of laser beam power in the range from 3.0 to $4.0 \mathrm{~kW}$ at a constant welding speed of $1.5 \mathrm{~m} / \mathrm{min}$ showed that the reduction of power mainly results in a decrease in the depth of penetration of the columnar part of the weld, without a clear change in the width of the weld at the contact of the sheets and a change in the shape of the upper (socket) part of the weld or the shape of the face (Fig. 16a and Fig. 18).

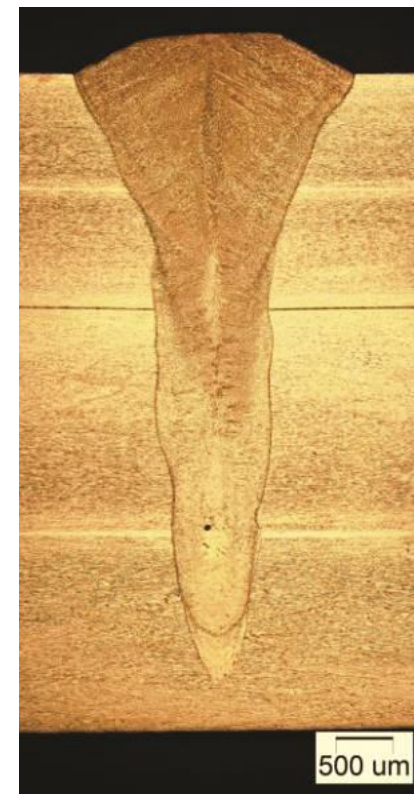

(a)

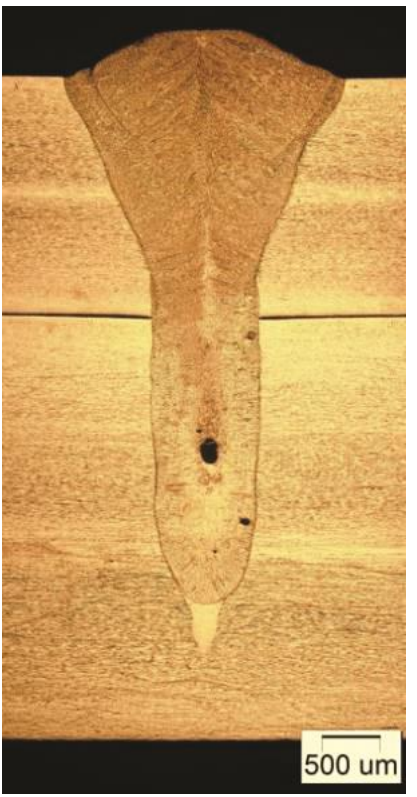

(b)

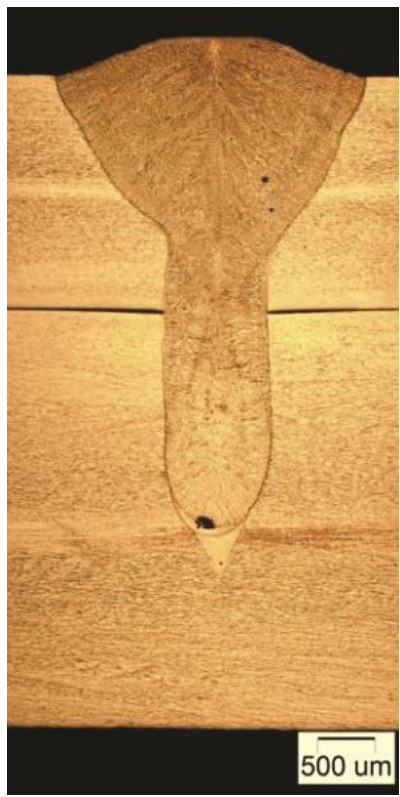

(c)

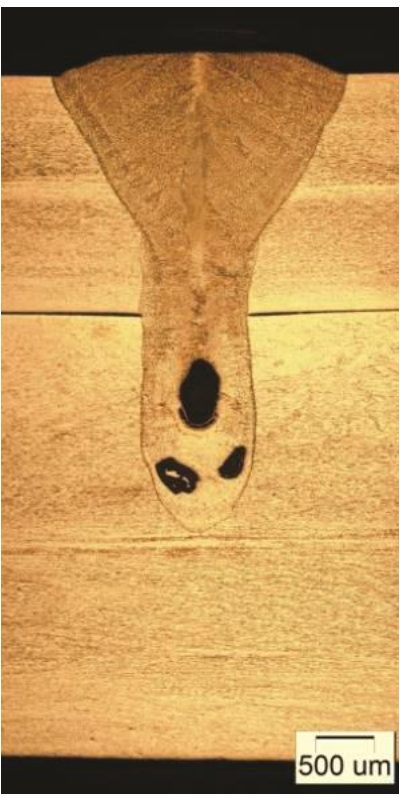

(d)

Fig. 18. Influence of the laser beam's power on the penetration depth and the shape of a straight weld of the lap joints of AISI 304 sheets with a thickness of $2.0 \mathrm{~mm}$ and $4.0 \mathrm{~mm}$ welded with a $\mathrm{CO}_{2}$ gas laser with a velocity of $1.5 \mathrm{~m} / \mathrm{min}$, with focusing of the laser beam in the plane of contact of the sheets: a) $3.75 \mathrm{~kW}$, b) $3.5 \mathrm{~kW}, \mathrm{c}) 3.25 \mathrm{~kW}$, d) $3.0 \mathrm{~kW}$

For test joints with circular welds with a diameter of $15 \mathrm{~mm}$, lower linear energy values from $60 \mathrm{~J} / \mathrm{mm}$ $(2.5 \mathrm{~kW}, 2.5 \mathrm{~m} / \mathrm{min})$ to $84 \mathrm{~J} / \mathrm{mm}(3.5 \mathrm{~kW}, 2.5 \mathrm{~m} / \mathrm{min})$ due to the phenomenon of heat accumulation and temperature increase in the welding area. Despite the lower welding linear energy, in the case of circular welds there is an increase in the depth of penetration into the lower plate along the perimeter of the weld (Fig. 19). However, the maximum penetration depth in the lower plate does not exceed $2.0 \mathrm{~mm}$ at the highest welding energy used. Macroscopic observations of test joints showed a tendency to create porosity and voids in the lower area of the columnar part of the weld (Fig. 16:18). At the same time, it was found that the tendency to create voids and pores in the lower part of the weld occurs in a specific range of laser welding parameters (low welding speeds and low laser beam powers), which indicates that the more likely cause of this phenomenon is instability of the steam channel (the so-called weld mesh) than the presence of impurities at the contact point of the sheets, as the sheet surfaces were cleaned and degreased before welding.

The microstructure of the weld and the area of the fusion line of welded joints with 240 and $80 \mathrm{~J} / \mathrm{mm}$ linear energy is shown in figure 20. The native material of AISI 304 steel has a typical banded austenitic structure, characteristic after rolling forming. The width of the heat affected zone along the fusion line depends on the welding linear energy, but even at the highest linear energy HAZ is narrow and its width does not exceed $200 \mu \mathrm{m}$, which is the effect of limited thermal impact during laser welding, but also the properties of AISI 304 steel, mainly low thermal conductivity. In the investigated welding energy range, no tendency to grain growth in the weld area was found. Column dendrites occur in this area, growing from the fusion 
line deep into the weld, creating a clear crystallization axis in the center of the weld. The fine-grained weld structure is advantageous due to the mechanical properties and plasticity of the weld metal.

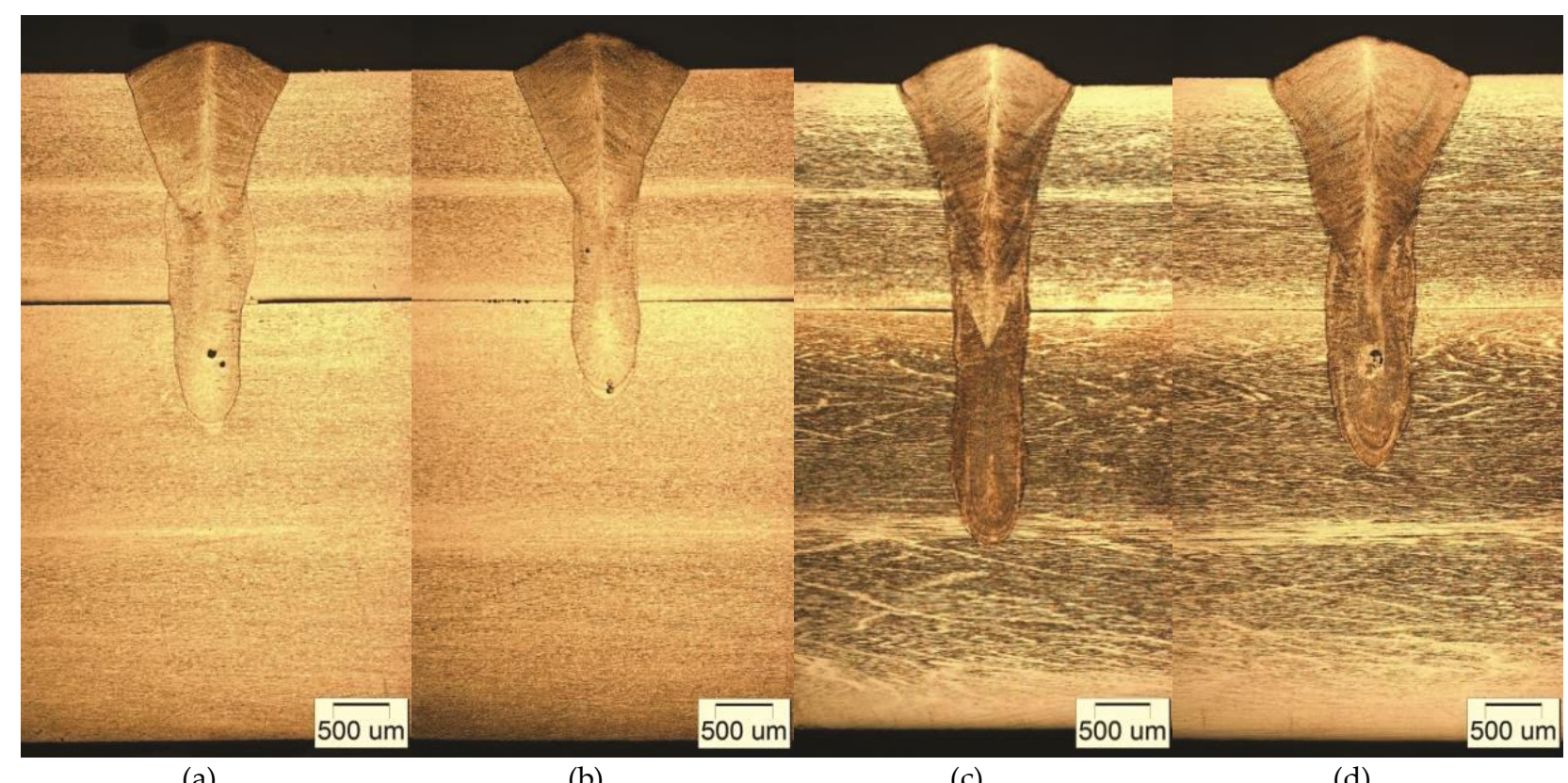

(a) (b)

(c)

(d)

Fig. 19. Influence of the laser beam's power on the penetration depth and the shape of a circular weld of the lap joints of AISI 304 sheets with a thickness of $2.0 \mathrm{~mm}$ and $4.0 \mathrm{~mm}$ welded with a $\mathrm{CO}_{2}$ gas laser with a velocity of $2.5 \mathrm{~m} / \mathrm{min}$, with focusing of the laser beam in the plane of contact of the sheets; a) $2.5 \mathrm{~kW}$, cross-section on the left side of the metallographic specimen, b) $2.5 \mathrm{~kW}$ cross-section on the right side of the metallographic specimen, c) $3.5 \mathrm{~kW}$, crosssection on the left side of the metallographic specimen, d) $3.5 \mathrm{~kW}$, cross-section on the right side of the metallographic specimen

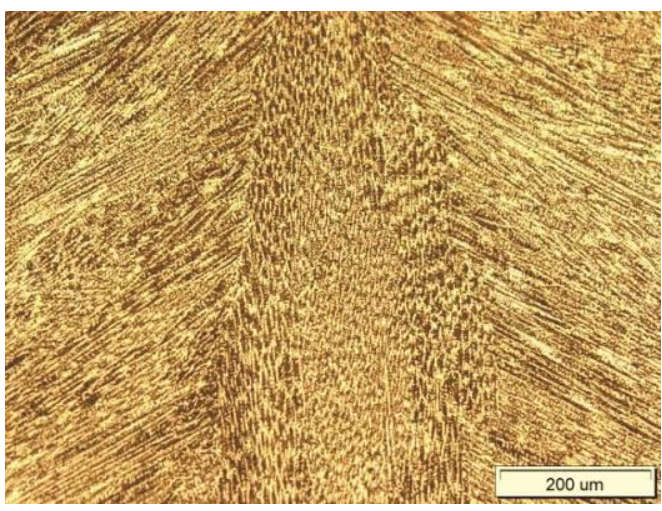

(a)

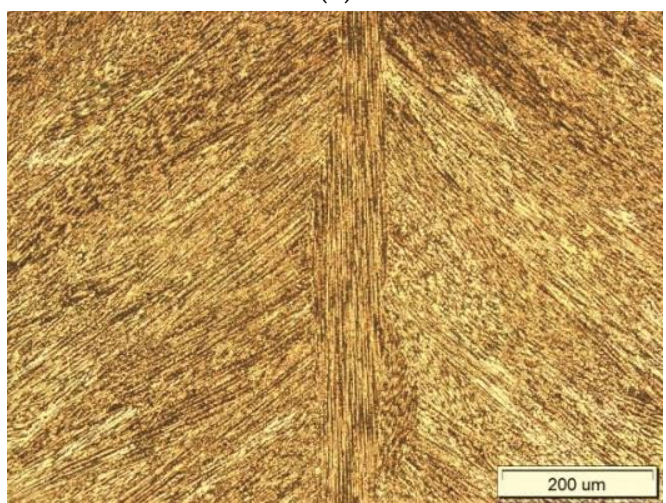

(c)

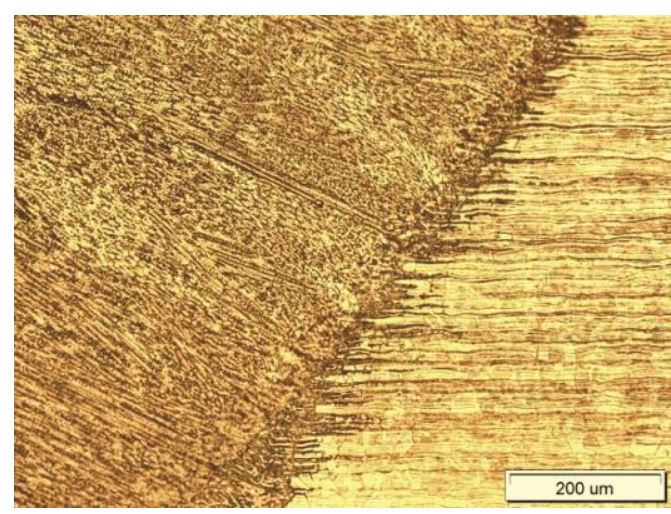

(b)

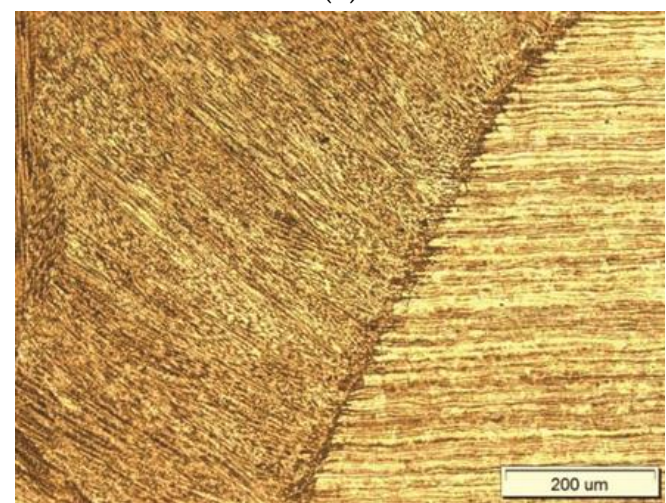

(d)

Fig. 20. Microstructure of the lap joints of AISI 304 sheets with a thickness of $2.0 \mathrm{~mm}$ and $4.0 \mathrm{~mm}$ with a straight weld made with $\mathrm{CO}_{2}$ gas laser with a power of $4.0 \mathrm{~kW}$, with focusing of the laser beam in the plane of contact of the sheets: $\mathrm{a}, \mathrm{b})$ from the left, the middle area of the weld and the weld line made at a welding speed of $1.0 \mathrm{~m} / \mathrm{min}(240 \mathrm{~J} / \mathrm{mm})$; c, d) the middle area of the weld and the weld line made at a welding speed of $3.0 \mathrm{~m} / \mathrm{min}(80 \mathrm{~J} / \mathrm{mm})$ 
Hardness measurements on the cross section of test joints show a clear dependence of the hardness in the weld on welding parameters, mainly welding linear energy (Fig. 21). At the hardness of the native material of $205 \div 210 \mathrm{HV} 0.2$, in the case of the lowest values of linear energy of welding joints with straight welds $(80 \mathrm{~J} / \mathrm{mm})$, the weld has a slight increase in hardness to the level of $220 \mathrm{HV} 0.2$. In turn, in the case of a weld made at the highest linear energy of $240 \mathrm{~J} / \mathrm{mm}$, an increase in hardness to approx. $250 \mathrm{HV} 0.2 \mathrm{was}$ recorded in the entire weld's cross-section.

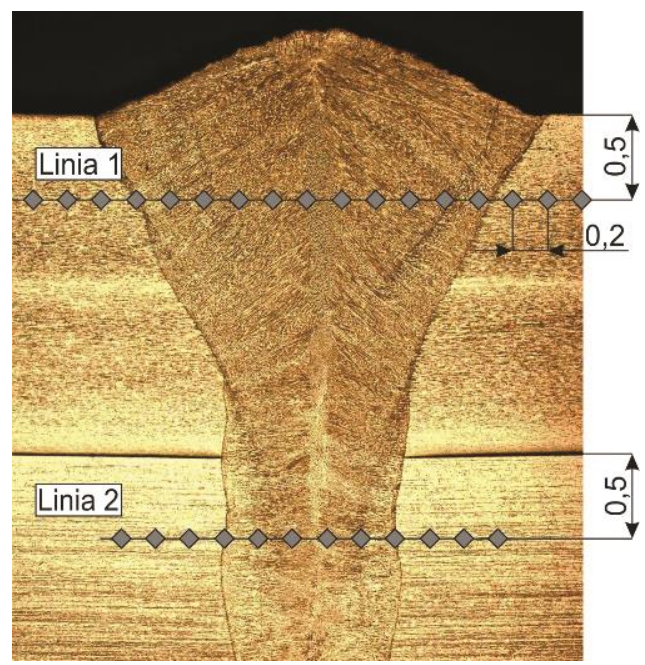

(a)

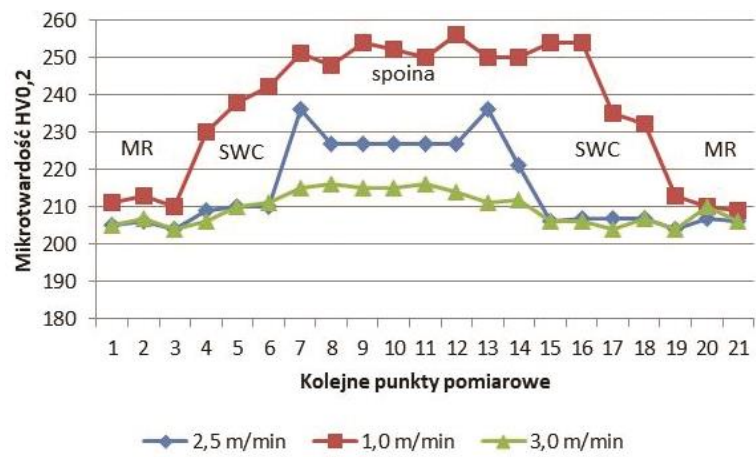

(b)

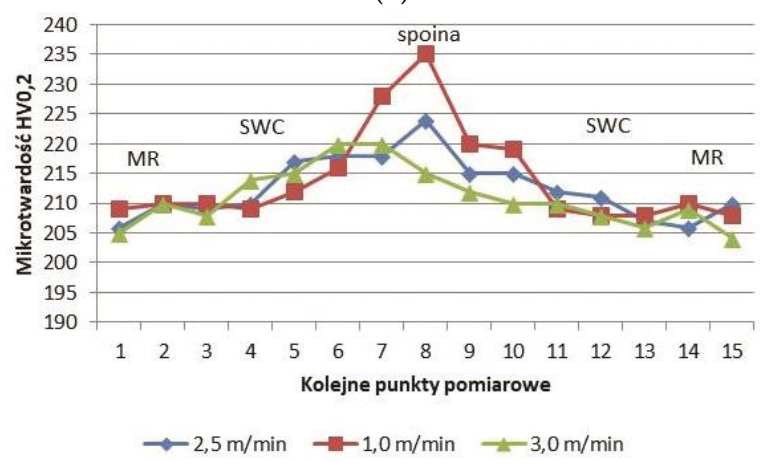

(c)

Fig. 21. a) Arrangement of lines and measuring points on the cross-section of the lap joints of AISI 304 sheets with a thickness of $2.0 \mathrm{~mm}$ and $4.0 \mathrm{~mm}$ welded with a $\mathrm{CO}_{2}$ gas laser with a power of $4.0 \mathrm{~kW}$, with focusing of the laser beam in the plane of contact of the sheets and different welding speeds; b) distribution of microhardness along the measurement line $1 ; \mathrm{c}$ ) distribution of microhardness along the measurement line 2

The results of tests of mechanical properties showed that samples with both straight and circular welds were broken in the weld (Fig. 23 and Fig. 24). This phenomenon is caused by the smaller cross-sectional area of the weld compared to the cross-section of thinner sheet (2.0 mm thick). However, in the case of test joints with circular welds, the breaking occurred after a significant plastic deformation of the sheets (relative deformation over 70\%) with a breaking force of even over $25 \mathrm{kN}$ (Fig. 22). In turn, for samples with straight welds, the relative tensile strength was determined by referring the value of the tensile force to the cross section of a thinner sheet, where the actual cross section of the weld depends on the welding parameters and is about $40 \div 50 \%$ smaller than the cross section of the sheet. For samples that were welded with a power of $4.0 \mathrm{~kW}$ and a speed of $1.5 \mathrm{~m} / \mathrm{min}$, the break occurred at a force of about $9 \mathrm{kN}$.

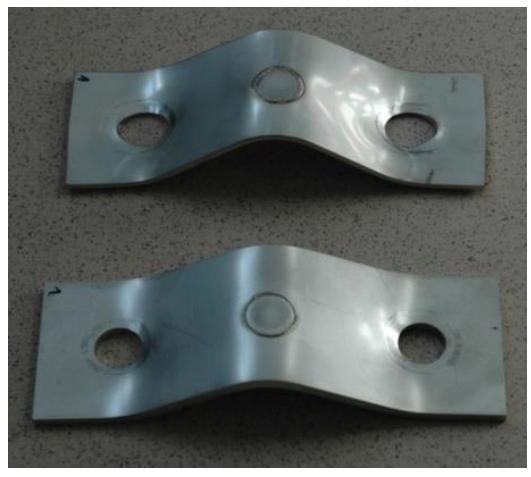

(a)

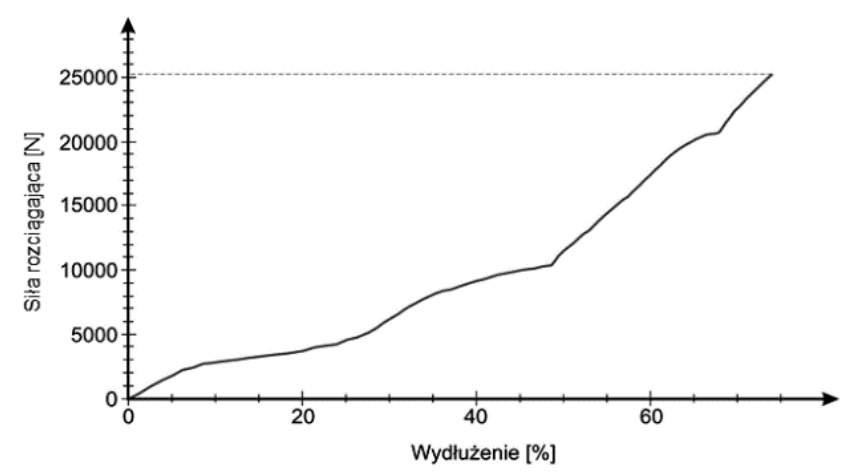

(b)

Fig. 22. View of the joint samples with a circular weld (welding parameters: $3.0 \mathrm{~kW}, 2.5 \mathrm{~m} / \mathrm{min}$, focusing $-2.0 \mathrm{~mm}$ ) after the static tensile test (a) and a stress-strain diagram (b) 


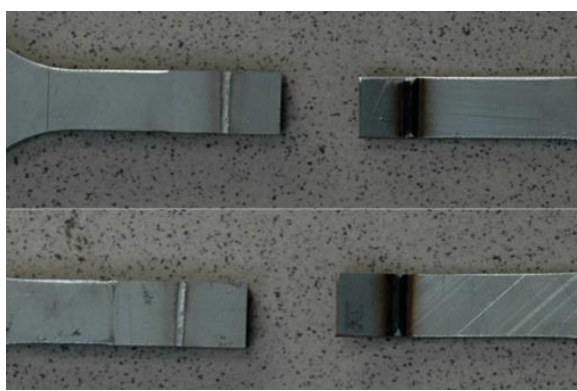

(a)

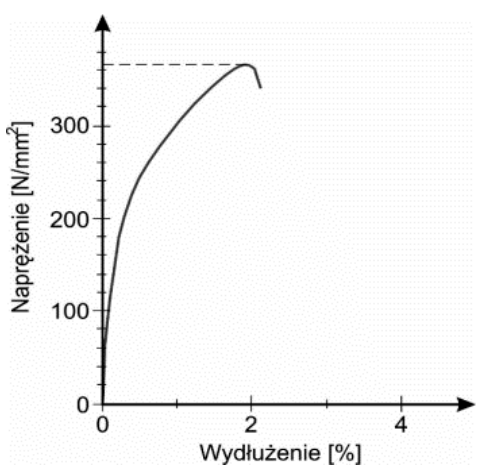

(b)

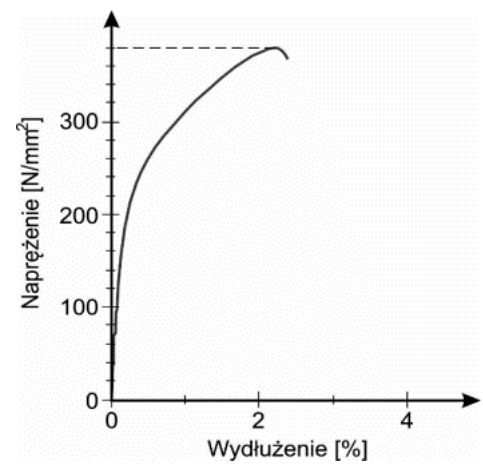

(c)

Fig. 23. View of samples of the lap joints with a straight weld (welding parameters: $4.0 \mathrm{~kW}, 1.5 \mathrm{~m} / \mathrm{min}$, focusing $-2.0 \mathrm{~mm}$ ) after a static tensile test $(\mathrm{a})$ and a stress-strain diagram $(\mathrm{b}, \mathrm{c})$ of samples which were ruptured at a strength of $8768 \mathrm{~N}$ and $9116 \mathrm{~N}$

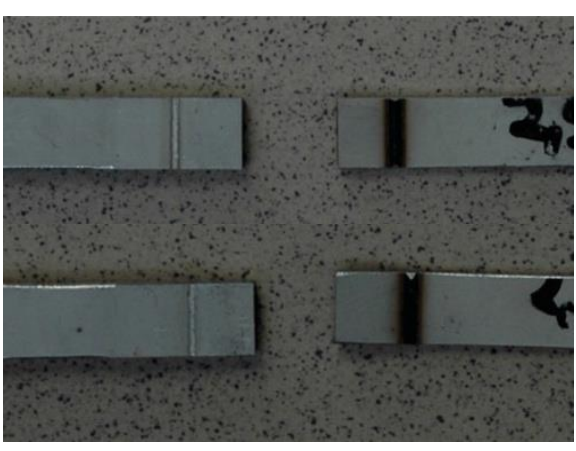

(a)

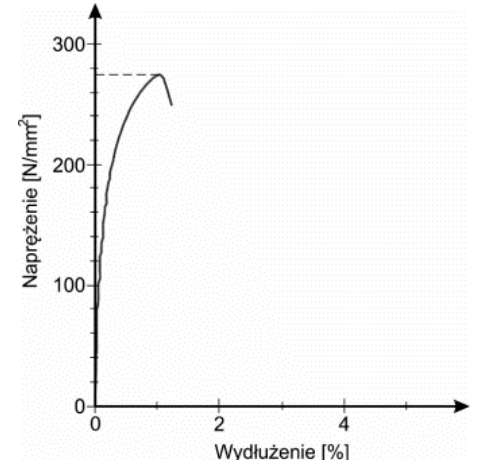

(b)

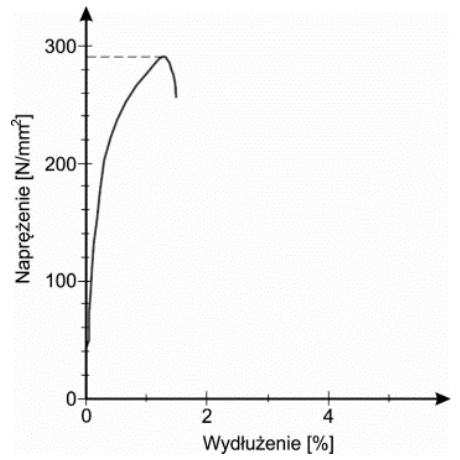

(c)

Fig. 24. View of samples of the lap joints with a straight weld (welding parameters: $4.0 \mathrm{~kW}, 2.5 \mathrm{~m} / \mathrm{min}$, focusing $-2.0 \mathrm{~mm}$ ) after a static tensile test $(\mathrm{a})$ and a stress-strain diagram $(\mathrm{b}, \mathrm{c})$ of samples which were ruptured at a strength of $6575 \mathrm{~N}$ and $6977 \mathrm{~N}$

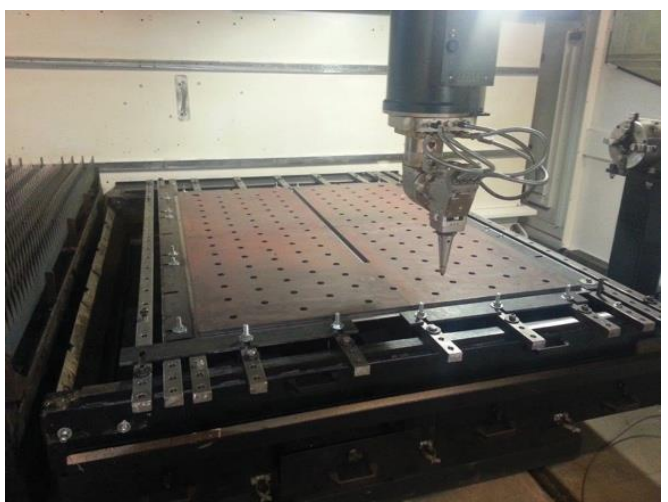

(a)

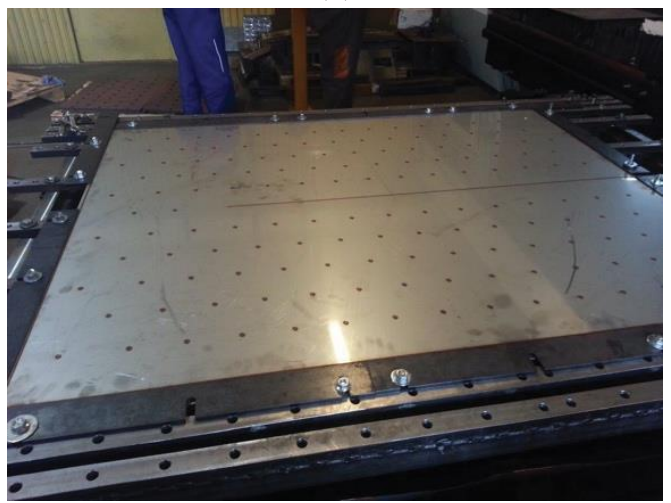

(c)

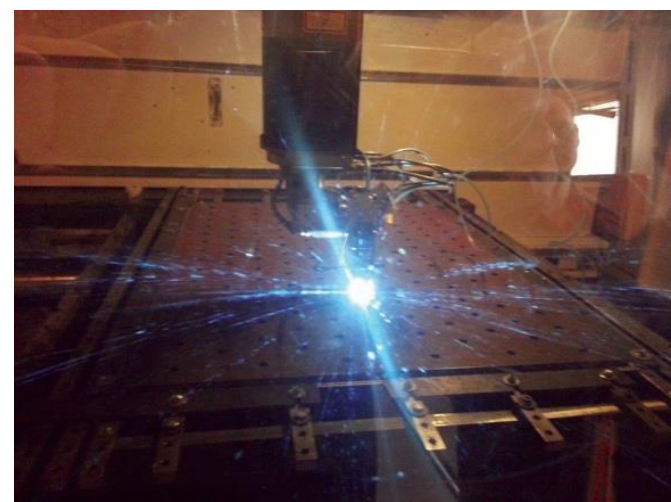

(b)

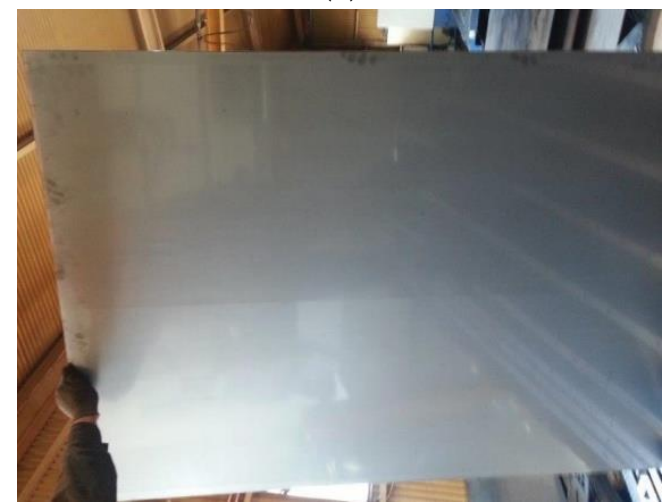

(d)

Fig. 25. a) View of the device for mounting the AISI 304 stainless steel sheets with a thickness of 2.0 and $4.0 \mathrm{~mm}$ for welding of the heat exchanger panels; b)view of the welding process of a panel with a $\mathrm{CO}_{2}$ gas laser beam; c) view of the top surface of the panel sheet with circular and linear welds and $d$ ) view of the bottom surface of the panel sheet (no traces of welding on the bottom surface) 
The results of testing the mechanical properties were considered positive, therefore ultimately $4.0 \mathrm{~kW}$ laser beam power and $1.5 \mathrm{~m} / \mathrm{min}$ welding speed were used as welding parameters for the appropriate $1.5 \times 1.5 \mathrm{~m}$ heat exchanger jackets and $3.0 \mathrm{~kW}$ and welding speed of $2.5 \mathrm{~m} / \mathrm{min}$ for circular welds with a diameter of $15 \mathrm{~mm}$ (Fig. 25). The batch of heat exchanger panels met the quality criteria specified by the customer and was received.

\section{Summary}

Tests and selection of parameters of the laser welding process of lap joints of AISI 304 austenitic steel sheets with a thickness of 2.0 and $4.0 \mathrm{~mm}$ with a $\mathrm{CO}_{2}$ gas laser with a maximum laser beam power of $4.0 \mathrm{~kW}$ allowed to determine the technological conditions for welding the heat exchanger panels with dimensions of $1.5 \times 1.5 \mathrm{~m}$. All heat exchanger panels made met the quality criteria specified by the customer.

It is possible to provide high quality lap joints of heat exchanger panels with straight-line and circular welds, with high strength and without heat tint on the bottom surface of the sheet (inner surface of the exchanger). However, due to the tendency to create voids and porosity in the lower fusion area during laser welding with the weld mesh technique, it is necessary to precisely select welding parameters so as to eliminate or reduce this phenomenon.

Laser welding of AISI 304 austenitic steel sheets due to the low welding linear energy values ensures a narrow heat-affected zone and favorable fine-grained weld structure, with a slight increase in weld hardness by approx. 20 to $25 \%$ relative to the native material.

Conflicts of Interest: The authors declare no conflict of interest.

\section{References}

[1] Dutka K., Laserowo spawane płaszcze grzewcze zbiorników ze stali austenitycznej. Welding Technology Review, 2009, Vol. 81(6),15-19.

[2] Świerczyńska A., Rogalski G., Fydrych D., Badania struktury i właściwości spawanych austenitycznych rur wymienników ciepła. Welding Technology Review, 2010, Vol. 82(6), 11-16.

[3] Rogalski G., Łabanowski J., Fydrych D., Świerczyńska A., Wpływ obróbki cieplnej na właściwości spawanych austenitycznych rur wymienników ciepła. Welding Technology Review, 2014, Vol. 86(6), 24-31. [CrossRef]

[4] Rogalski G., Fydrych D., Prokop-Strzelczyńska K., Napawanie elementów wymiennika ciepła austenitycznym drutem proszkowym. Welding Technology Review, 2017, Vol.89(3), 13-18. [CrossRef]

[5] Stano S., Chrobak G., Zrobotyzowane stanowisko do spawania laserowego. Biuletyn Instytutu Spawalnictwa, 2011, Vol. 55(3), 23-26.

[6] Kurc-Lisiecka A., Spawanie laserowe złączy doczołowych z austenitycznej stali nierdzewnej AISI 30., STAL Metale ENowe Technologie, 2016, 11-12, 40-44.

[7] Arivazhagan N., Singh S., Prakash S., Reddy G.M., Investigation on AISI 304 austenitic stainless steel to AISI 4140 low alloy steel dissimilar joints by gas tungsten arc, electron beam and friction welding. Materials and Design, 2011, Vol. 32(5), 3036-3050. [CrossRef]

[8] Lisiecki A., Kurc-Lisiecka A., Automated Laser Welding of AISI 304 Stainless Steel by Disk Laser, Archives of Metallurgy and Materials, 2018, Vol. 63(4), 1663-1672. [CrossRef]

[9] Konuk A.R., et al., Process Control of Stainless Steel Laser Welding using an Optical Spectroscopic Sensor, Physics Procedia, 2011, Vol. 12, 744-751. [CrossRef]

(C) 2019 by the authors. Submitted for possible open access publication under the terms and conditions of the Creative Commons Attribution (CC BY) license (http://creativecommons.org/licenses/by/4.0/). 